\title{
OPTIMISING EXTERNAL TURNING TOOL CHOICE USING AHP AND ELECTRE II METHODS
}

\author{
Zlatko Botak, Jože Balič, Zoran Jurković
}

Original scientific paper It is preferable to remove as much raw material in as short time as possible when processing materials using rough turning methods. Selecting the correct cutting tool at the beginning of the process is very important as this reduces the amount of material requiring later processing, in turn reducing the number of turning tools required, the number of tool changes and the total time taken to make a piece. In this paper, we present a system for selecting the best tools for external longitudinal turning. We take into account the characteristics of the machine, the power needed for cutting, the geometry and technological characteristics of the tools, and the machining parameters. Selection of the best tool for rough machining is made based on the processing time, the percentage of material to be cut, the cost of the tools and the number of tool changes. We ranked eight tools and used the analytical hierarchy process (AHP) method for multi-criteria optimisation then evaluated the results using ELECTRE II methods. The weight criteria were estimated using Saaty's pairwise comparison scale.

Keywords: analytic hierarchy process; ELECTRE II method; multi-criteria decision-making; tool selection

Izbor optimalnog alata za vanjsko tokarenje pomoću AHP i ELECTRE II metode

Izvorni znanstveni članak

Prilikom obrade vanjskim grubim tokarenjem poželjno je skinuti što više materijala sa sirovog komada u što kraćem vremenu. Vrlo je važno izabrati tokarski nož koji prvi započinje obradu, kako bi ostatak materijala za kasniju obradu bio što manji. Time se smanjuje ukupno potrebni broj alata za tokarenje, broj izmjena alata te ukupno vrijeme izrade komada. U radu je prikazan sistem za izbor najpovoljnijeg alata za vanjsko uzdužno tokarenje uz uvažavanje karakteristika stroja, snage potrebne za rezanje, geometriju i tehnološke karakteristike alata te parametara obrade. Izbor najoptimalnijeg alata za grubu obradu izvršen je prema kriterijima vrijeme obrade, postotak odrezanoga materijala, cijena alata po reznoj oštrici te broju prolaza alata. Kod rangiranja rezultata obrade za 8 alata korištena je metoda za višekriterijsku optimizaciju AHP, a rezultati su dodatno vrednovani po ELECTRE II metodi. Vrijednosti težina kriterija procijenjene su prema Saty-jevoj ljestvici usporedbe kriterija u parovima.

Ključne riječi: analitički hijerarhijski proces; ELECTRE II metoda; izbor alata; višekriterijsko odlučivanje

\section{Introduction}

Due to the complexity of the production system and design process, meeting the requirements of contemporary modern manufacturing requires the use of artificial intelligence. The aim is to develop a process model that describes the complex relationship between the input and output values realistically. This will enable us to manage, analyse and optimise solutions for streaming the processing in real time.

Turning requires a number of rough passes followed by finish passes. Each tool movement is executed under geometric and technological constraints such as the cutting tool geometry, material properties, cutting parameters, machine capabilities etc.

Many researchers have worked on modelling a system to perform geometrical feature recognition and determine optimal machining parameters.

According to the literature [1], current intelligent computer-aided design and computer-aided manufacturing (CAD-CAM) systems consist of two main parts, the recogniser and the searcher. Using a system based on a genetic algorithm to recognise features, we determine cutting tools, parameters and tool path plans.

An ant colony optimisation algorithm combined with a neuro-fuzzy inference system has been presented [2] for use in selecting optimal cutting parameters. This will reduce machining costs and increase the production rate. Turning operation was defined as a multi-objective optimisation problem with limiting nonlinear equations and with three conflict objectives: production rate, operation cost and quality of machining.

An intelligent system for selecting the best set of tools has been described [2]. This is based on a 3D CAD model and other relevant selection factors and uses a neural network.

An applied model based on an artificial neural network [4] has been used to predict wear at the flank face of the cutting inserts and the roughness of the machined workpiece's surface during the hard turning process.

In [5] proper combinations of cutting tools were determined by generating tool paths and optimising machining parameters using an example of the milling process. A model for optimising machining parameters was developed as a nonlinear programming problem.

In [6] an implementation of a particle swarm tool is presented. This solves the multi-objective optimisation problem of finding suitable manufacturing techniques, with respect to ecological, economic and technological constraints. Determining optimal cutting parameters that minimise the time, cost and energy consumption during the roughing operation was the main objective of this research.

The turning process has also been modelled using a gravitational search algorithm. This optimises the numerical coefficients of predefined polynomial models for describing the observed output variables [7]. The results for rough turning and finishing were presented separately.

\section{AHP and Electre II methods}

The analytical hierarchy process (AHP) is a method for solving multi-criteria problems by splitting them into several levels. The goal to be achieved is at the top level, the criteria are at the lower levels and the available alternatives are at the lowest level. 
The mathematical model is based on an assessment of the importance of certain mutual ratio criteria according to Saaty's scale. The decision-maker compares the main criteria in pairs, according to their importance with respect to achieving the final goal. It forms a judgement matrix, which is then normalised. This results in calculation of the weight of each criterion, and the priority of each alternative. Alternatives are ranked at the end.

In the ELECTRE II method, the alternatives are compared so the deficiencies of a criterion cannot be compensated for by other advantages. Vectors and weighted decision tables are used to normalise the initial table of values. After that, the concordance and discordance index matrices are specified. The concordance index matrix is created by adding the weight criteria, according to which the $a_{k}$ alternative is not weaker than $a_{i}$. The discordance index matrix is obtained by finding the biggest difference in the criteria when $a_{i}$ is better than $a_{k}$, then dividing by the absolute value of the differences between all the criteria. The pure concordance and pure discordance indexes, calculated at the end, allow ranking of the alternatives.

\section{Input data}

We collected technical data for eight external roughing tools for the purpose of the experiment. The system for multi-criteria decision-making is composed of separate modules for processing geometry and technology, as shown in Fig. 1.

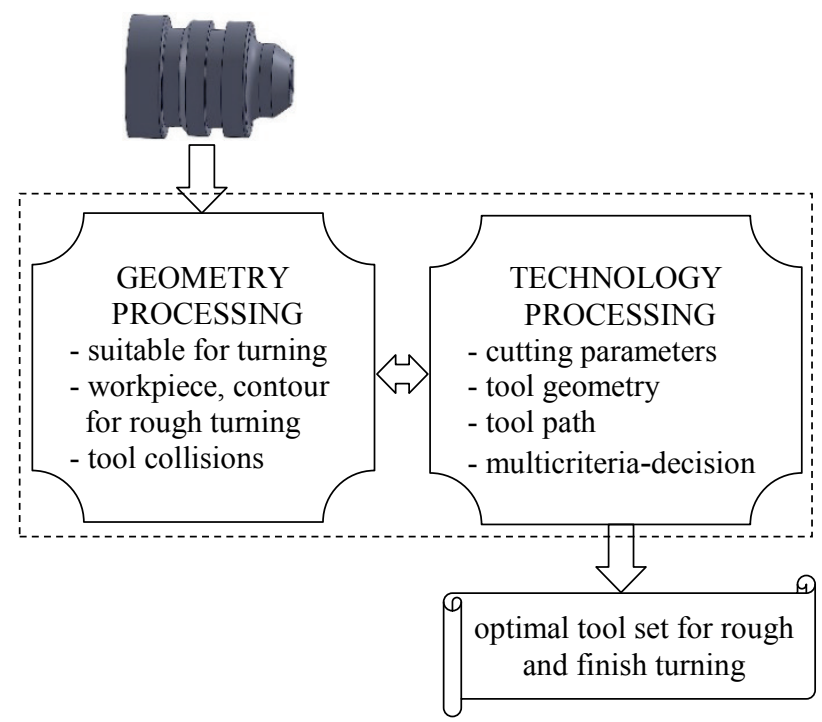

Figure 1 Structure of the multicriteria decision system

Using a 3D model system, we generated both workpiece contours and contours for rough turning. After each pass of a cutting tool, the contours are compared. When the tool cannot cut the material or the contours are equal, the cutting tool is changed and the processes to be performed by the next available tool are planned.

The power necessary for cutting and the cutting speed, are limited (constant), and the cutting depth, feed rate and spindle speed change.

During the processing, the cutting depth, feed and spindle speed must stay within the technological values recommended by the manufacturers.
If the processing is carried out at a constant cutting depth $a_{p}$, then the feed rate is determined by the expression:

$f=10 \frac{\log \left(\frac{a_{p} \cdot d \cdot \pi \cdot n \cdot k_{c, 1 x 1}}{P_{r} \cdot 6 \times 10^{7}}\right)}{z-1}$

If the feed rate is constant, the maximum possible cutting depth is calculated by the following formula:

$a_{p}=\frac{6 \times 10^{7} \cdot f^{z_{1}} \cdot P_{r}}{f_{\max } \cdot k_{c, 1 x 1} \cdot d \cdot \pi \cdot n}$

where $a_{p}$ is the depth of the cut, $f$ is the feed rate, $d$ is the outer diameter of the workpiece, $n$ is the spindle speed, $k_{c 1 x 1}$ is the specific cutting force, $P_{r}$ is the cutting power required for turning and $z$ is the exponent of the material thickness.

The cutter inserts for turning have two, three or four cutting edges and the cost per cutting edge is calculated in each case. Other data output from the program are the number of tool passes, the duration of the pass and the percentage of the rough contouring process. Tab. 1 shows the results for each tool.

Table 1 Processing data for tools

\begin{tabular}{|c|c|c|c|c|}
\hline Tool n. & CT/s & MRR/\% & PR/€ & NP/ \\
\hline T1 & 27,45 & 96,94 & 1,1 & 6 \\
\hline T2 & 37,35 & 98,88 & 1,8 & 11 \\
\hline T3 & 37,18 & 98,67 & 1 & 11 \\
\hline T4 & 71,23 & 99,57 & 2 & 11 \\
\hline T5 & 30,26 & 97,24 & 1 & 5 \\
\hline T6 & 61,23 & 97,2 & 0,9 & 11 \\
\hline T7 & 35,95 & 98,72 & 1,2 & 4 \\
\hline T8 & 34,54 & 98,92 & 1,8 & 7 \\
\hline
\end{tabular}

The goal is to select the best tool to start the processing based on four different criteria: cutting time, percentage of the material cut from the raw material, price of the tools and the number of passes.

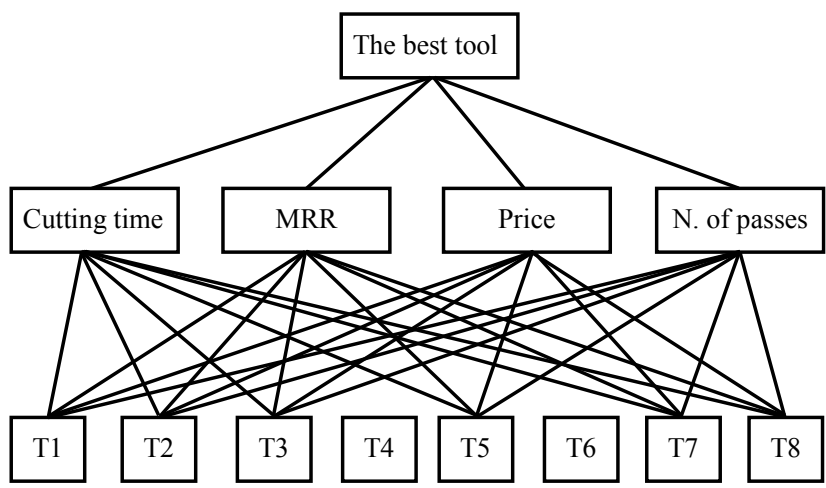

Figure 2 Analytical hierarchy process (AHP) hierarchy model

\section{The selection of the best tool by using AHP method}

According to the AHP method, the problem of choosing the best tool can be broken down into three levels: as shown in Fig. 2, the goal is at the highest level (the best processing tool), while the options are at the 
lowest levels. These correspond to the available treatment tools.

Using the mathematical method developed by Thomas L. Saaty, we estimate the importance of each criterion [12]. The cutting time criterion $(C T)$ is less important than the processing percentage criterion $(M R R)$, but more important than the price criterion $(P R)$ and the number of tool passes $(N P)$, etc. Other ratios are shown in Tab. 2, which is symmetrical around the main diagonal.

Table 2 The judgement matrix

\begin{tabular}{|c|c|c|c|c|}
\hline & $C T$ & $M R R$ & $P R$ & $N P$ \\
\hline$C T$ & 1 & 3 & 5 & 7 \\
\hline$M R R$ & $1 / 3$ & 1 & 3 & 7 \\
\hline$P R$ & $1 / 5$ & $1 / 3$ & 1 & 3 \\
\hline$N P$ & $1 / 7$ & $1 / 7$ & $1 / 3$ & 1 \\
\hline$\Sigma$ & 1,676 & 4,476 & 9,333 & 18 \\
\hline
\end{tabular}

The values of the weights of the criteria are obtained by first calculating the sum of all columns of ratios (Tab. 2). After that, each value from Tab. 2 is divided by the value of the corresponding column to obtain normalised values. Finally, the values of individual lines are summed and the weight of each criterion of $w_{i}$ is calculated according to:

$w_{i}=\frac{1}{n} \cdot \sum_{j=1}^{n} \frac{b_{i j}}{\sum_{i=1}^{n} b_{i j}}$.

The normalised value matrix ratio and the calculated weight of all the criteria are shown in Tab. 3 .

Table 3 Priority vector $w_{\mathrm{i}}$
\begin{tabular}{|c|c|c|c|c|c|}
\hline & $C T$ & $M R R$ & $P R$ & $N P$ & $w_{\mathrm{i}}$ \\
\hline$C T$ & 0,597 & 0,67 & 0,536 & 0,389 & 0,548 \\
\hline$M R R$ & 0,199 & 0,223 & 0,321 & 0,389 & 0,283 \\
\hline$P R$ & 0,119 & 0,074 & 0,107 & 0,167 & 0,117 \\
\hline$N P$ & 0,085 & 0,032 & 0,036 & 0,056 & 0,052 \\
\hline
\end{tabular}

Table 4 Tool data evaluation

\begin{tabular}{|c|c|c|c|c|}
\hline Tool & $C T$ & $M R R$ & $P R$ & $N P$ \\
\hline 1 & 1 & 9 & 2 & 3 \\
\hline 2 & 3 & 3 & 8 & 9 \\
\hline 3 & 3 & 4 & 1 & 9 \\
\hline 4 & 9 & 1 & 9 & 9 \\
\hline 5 & 1 & 8 & 1 & 2 \\
\hline 6 & 7 & 9 & 1 & 9 \\
\hline 7 & 2 & 3 & 3 & 1 \\
\hline 8 & 2 & 3 & 8 & 4 \\
\hline
\end{tabular}

The data in Tab. 1 are evaluated linearly from 1 (best) to 9 (worst). The intermediate data, which need to be minimised, (cutting time, price, number of passes) are calculated according to the formula:

$c_{i j}=\operatorname{roundup}\left(\frac{9 \cdot\left(a_{i j}-a_{\min }\right)}{a_{j \max }-a_{j \min }}\right)$.

or, for data that require the maximum value (processing percentage), according to the formula: $c_{i j}=\operatorname{roundup}\left(\frac{9 \cdot\left(a_{j \max }-a_{i j}\right)}{a_{j \max }-a_{j \min }}\right)$.

The results for all eight tools are shown in Tab. 4, and they are used to compare alternatives with respect to each criterion.

Pairwise comparison of alternatives is carried out by calculating the absolute differences of alternative values, according to:

$d_{i j}=c_{j}-c_{i}+1$

when $c_{j}-c_{i}>0$, or

$d_{i j}=\frac{1}{\operatorname{abs}\left(\mathrm{c}_{j}-c_{i}\right)+1}$.

when $c_{j}-c_{i}<0$. The results are shown in Tab. 5 .

Table 5 Importance ratios according to the processing time criterion

\begin{tabular}{|c|c|c|c|c|c|c|c|c|}
\hline Tooln. & 1 & 2 & 3 & 4 & 5 & 6 & 7 & 8 \\
\hline 1 & 1 & 3 & 3 & 9 & 1 & 7 & 2 & 2 \\
\hline 2 & 0,333 & 1 & 1 & 7 & 0,333 & 5 & 0,5 & 0,5 \\
\hline 3 & 0,333 & 1 & 1 & 7 & 0,333 & 5 & 0,5 & 0,5 \\
\hline 4 & 0,111 & 0,143 & 0,143 & 1 & 0,111 & 0,333 & 0,125 & 0,125 \\
\hline 5 & 1 & 3,003 & 3,003 & 9,009 & 1 & 7 & 2 & 2 \\
\hline 6 & 0,143 & 0,2 & 0,2 & 3,003 & 0,143 & 1 & 0,167 & 0,167 \\
\hline 7 & 0,5 & 2 & 2 & 8 & 0,5 & 5,988 & 1 & 1 \\
\hline 8 & 0,5 & 2 & 2 & 8 & 0,5 & 5,988 & 1 & 1 \\
\hline$\sum$ & 3,92 & 12,346 & 12,346 & 52,012 & 3,92 & 37,309 & 7,292 & 7,292 \\
\hline
\end{tabular}

The priority vector $\boldsymbol{P}_{i}$ is now calculated for the four criteria. Each value in the table is divided by the sum of the corresponding column to get normalised values; then, the sum of the rows is divided by the number of rows.

$$
\boldsymbol{P}_{i}=\frac{1}{n} \cdot \sum_{j=1}^{n} \frac{d_{i j}}{\sum_{i=1}^{n} d_{i j}}
$$

Table 6 Priority according to the cutting time criterion

\begin{tabular}{|c|c|c|c|c|c|c|c|c|c|}
\hline Tool $\mathrm{n}$ & 1 & 2 & 3 & 4 & 5 & 6 & 7 & 8 & $\boldsymbol{P}_{i}$ \\
\hline 1 & 0,255 & 0,243 & 0,243 & 0,173 & 0,255 & 0,188 & 0,274 & 0,274 & 0,238 \\
\hline 2 & 0,085 & 0,081 & 0,081 & 0,135 & 0,085 & 0,134 & 0,069 & 0,069 & 0,092 \\
\hline 3 & 0,085 & 0,081 & 0,081 & 0,135 & 0,085 & 0,134 & 0,069 & 0,069 & 0,092 \\
\hline 4 & 0,028 & 0,012 & 0,012 & 0,019 & 0,028 & 0,009 & 0,017 & 0,017 & 0,018 \\
\hline 5 & 0,255 & 0,243 & 0,243 & 0,173 & 0,255 & 0,188 & 0,274 & 0,274 & 0,238 \\
\hline 6 & 0,036 & 0,016 & 0,016 & 0,058 & 0,036 & 0,027 & 0,023 & 0,023 & 0,029 \\
\hline 7 & 0,128 & 0,162 & 0,162 & 0,154 & 0,128 & 0,16 & 0,137 & 0,137 & 0,146 \\
\hline 8 & 0,128 & 0,162 & 0,162 & 0,154 & 0,128 & 0,16 & 0,137 & 0,137 & 0,146 \\
\hline
\end{tabular}

The function value for each tool $F$ is created by adding the product of the priorities and the corresponding weight factor $w_{i}$ according to:

$$
F=\frac{1}{n} \cdot \sum_{j=1}^{n} P_{i}
$$

The values obtained for each tool are shown in Tab. 7. The higher the value of $F$, the better the tool is for 
rough processing. The rankings list of the rough turning tools are shown in Tab. 8.

Table 7 Priority and objective function

\begin{tabular}{|c|c|c|c|c|c|}
\hline \multicolumn{5}{|c|}{ Table 7 Priority and objective function } \\
\hline & 0,548 & 0,283 & 0,117 & 0,052 & \\
\hline Tool & $C T$ & $M R R$ & $P R$ & $N P$ & $F$ \\
\hline 1 & 0,238 & 0,023 & 0,146 & 0,175 & 0,163 \\
\hline 2 & 0,092 & 0,158 & 0,027 & 0,028 & 0,1 \\
\hline 3 & 0,092 & 0,106 & 0,226 & 0,028 & 0,108 \\
\hline 4 & 0,018 & 0,34 & 0,019 & 0,028 & 0,11 \\
\hline 5 & 0,238 & 0,033 & 0,226 & 0,242 & 0,179 \\
\hline 6 & 0,029 & 0,023 & 0,226 & 0,028 & 0,05 \\
\hline 7 & 0,146 & 0,158 & 0,104 & 0,34 & 0,155 \\
\hline 8 & 0,146 & 0,158 & 0,027 & 0,131 & 0,135 \\
\hline
\end{tabular}

Table 8 Final tool ranking
\begin{tabular}{|c|c|c|c|c|c|c|c|c|}
\hline Rank & 1 & 2 & 3 & 4 & 5 & 6 & 7 & 8 \\
\hline Tool & 5 & 1 & 7 & 8 & 4 & 3 & 2 & 6 \\
\hline$F$ & 0,179 & 0,163 & 0,155 & 0,135 & 0,110 & 0,108 & 0,100 & 0,050 \\
\hline
\end{tabular}

Finally, the consistency assessment index is calculated. This shows whether the importance ratios of certain criteria are properly decided. The consistency index $(C I)$ is:

$C I=\frac{\lambda_{\max }-n}{n-1}=\frac{4,137-4}{4-1}=0,046$.

The $C R$ consistency ratio is now calculated. This must be less than $10 \%$.

$C R=\frac{C I}{R I}=\frac{0,046}{0,89}=0,052=5,2 \%<10 \%$.

The $C R$ consistency ratio shows that the estimates of the relative importance ratios are acceptable.

\section{The selection of the best tools based on Electre II method}

To use the ELECTRE II method, the data must be normalised using vector normalisation. To do this, the column elements are divided by the root of the sum of squares of all elements of the same column, according to:

$$
b_{i j}=\frac{a_{i j}}{\sqrt{\sum_{i=1}^{n} a_{i j}^{2}}}
$$

In the case of criteria which must be minimised, we use:

$$
b_{i j}=1-\frac{a_{i j}}{\sqrt{\sum_{i=1}^{n} a_{i j}^{2}}}
$$

The normalised data from Tab. 1 are shown in Tab. 9.

The rank list of alternatives is obtained by comparing data from the matrix of the concordance index $\mathrm{C}$ to the matrix of discordance index D.
Table 9 Normalised matrix (ELECTRE II)

\begin{tabular}{|c|c|c|c|c|}
\hline Tool & $C T$ & $M R R$ & $P R$ & $N P$ \\
\hline 1 & 0,781 & 0,349 & 0,724 & 0,757 \\
\hline 2 & 0,702 & 0,356 & 0,549 & 0,555 \\
\hline 3 & 0,704 & 0,355 & 0,750 & 0,555 \\
\hline 4 & 0,433 & 0,358 & 0,499 & 0,555 \\
\hline 5 & 0,759 & 0,350 & 0,750 & 0,798 \\
\hline 6 & 0,512 & 0,350 & 0,775 & 0,555 \\
\hline 7 & 0,714 & 0,355 & 0,699 & 0,838 \\
\hline 8 & 0,725 & 0,356 & 0,549 & 0,717 \\
\hline
\end{tabular}

Then, the weighted values in Tab. 9 are multiplied by the weight of each criterion, shown in Tab. 3. Hence, the relative importance of each criterion is deduced.

Table 10 Weighted matrix

\begin{tabular}{|c|c|c|c|c|}
\hline Tool num. & $C T$ & $M R R$ & $P R$ & $N P$ \\
\hline 1 & 0,428 & 0,099 & 0,085 & 0,039 \\
\hline 2 & 0,385 & 0,101 & 0,064 & 0,029 \\
\hline 3 & 0,386 & 0,100 & 0,088 & 0,029 \\
\hline 4 & 0,237 & 0,101 & 0,058 & 0,029 \\
\hline 5 & 0,416 & 0,099 & 0,088 & 0,041 \\
\hline 6 & 0,281 & 0,099 & 0,091 & 0,029 \\
\hline 7 & 0,391 & 0,100 & 0,082 & 0,044 \\
\hline 8 & 0,397 & 0,101 & 0,064 & 0,037 \\
\hline
\end{tabular}

The elements of the matrix of concordance index C, shown in Tab. 11, are obtained by summing the values of the criteria according to which the alternative $a_{i}$ is equal to or better than the alternative $a_{k}$.

Table 11 Matrix C

\begin{tabular}{|c|c|c|c|c|c|c|c|c|}
\hline & $A_{1}$ & $A_{2}$ & $A_{3}$ & $A_{4}$ & $A_{5}$ & $A_{6}$ & $A_{7}$ & $A_{8}$ \\
\hline$A_{1}$ & 0 & 0,717 & 0,6 & 0,717 & 0,831 & 0,883 & 0,665 & 0,717 \\
\hline$A_{2}$ & 0,283 & 0 & 0,335 & 1 & 0,283 & 0,883 & 0,283 & 0,4 \\
\hline$A_{3}$ & 0,4 & 0,717 & 0 & 0,717 & 0,4 & 0,883 & 0,4 & 0,117 \\
\hline$A_{4}$ & 0,283 & 0,335 & 0,335 & 0 & 0,283 & 0,335 & 0,283 & 0,283 \\
\hline$A_{5}$ & 0,452 & 0,717 & 0,717 & 0,717 & 0 & 0,883 & 0,665 & 0,717 \\
\hline$A_{6}$ & 0,4 & 0,169 & 0,169 & 0,717 & 0,4 & 0 & 0,117 & 0,117 \\
\hline$A_{7}$ & 0,335 & 0,717 & 0,883 & 0,717 & 0,335 & 0,883 & 0 & 0,169 \\
\hline$A_{8}$ & 0,283 & 1 & 0,883 & 1 & 0,283 & 0,883 & 0,831 & 0 \\
\hline
\end{tabular}

The elements of the matrix of discordance index D are obtained by comparison of the greatest difference of criteria by which $a_{i}$ is better than $a_{k}$, and is divided by the biggest difference of all the criteria, Tab. 12.

Table 12 Matrix D

\begin{tabular}{|c|c|c|c|c|c|c|c|c|}
\hline & $A_{1}$ & $A_{2}$ & $A_{3}$ & $A_{4}$ & $A_{5}$ & $A_{6}$ & $A_{7}$ & $A_{8}$ \\
\hline$A_{1}$ & 0 & 1 & 0,168 & 1 & 1 & 1 & 1 & 1 \\
\hline$A_{2}$ & 0,618 & 0 & 0,003 & 1 & 0,759 & 1 & 1 & 1 \\
\hline$A_{3}$ & 1 & 1 & 0 & 1 & 1 & 1 & 1 & 1 \\
\hline$A_{4}$ & 0,021 & 0,008 & 0,006 & 0 & 0,022 & 0,091 & 0,011 & 0,007 \\
\hline$A_{5}$ & 0,273 & 1 & 0,12 & 1 & 0 & 1 & 1 & 1 \\
\hline$A_{6}$ & 0,042 & 0 & 0 & 1 & 0,021 & 0 & 0,088 & 0,254 \\
\hline$A_{7}$ & 0,136 & 0,623 & 0,073 & 1 & 0,114 & 1 & 0 & 1 \\
\hline$A_{8}$ & 0,091 & 0,239 & 0,041 & 1 & 0,106 & 1 & 0,314 & 0 \\
\hline
\end{tabular}

To rank the alternatives, we calculate the pure concordance index $c_{k}$ according to [16]:

$c_{k}=\sum_{\substack{i=1 \\ i \neq k}}^{n} c_{k i}-\sum_{\substack{i=1 \\ i \neq k}}^{n} c_{i k}$, 
and the pure discordance index $d_{k}$ according to:

$$
d_{k}=\sum_{\substack{i=1 \\ i \neq k}}^{n} d_{k i}-\sum_{\substack{i=1 \\ i \neq k}}^{n} d_{i k}
$$

The values obtained for the indices $c_{k}$ and $d_{k}$ are shown in Tab. 13. Based on these data, it is possible to rank the alternatives, as in Tab. 14, and select the best processing tool.

Table 13 Matrix indexes $C$ and $D$

\begin{tabular}{|c|c|c|c|c|c|c|c|}
\hline$C_{1}$ & $C_{2}$ & $C_{3}$ & $C_{4}$ & $C_{5}$ & $C_{6}$ & $C_{7}$ & $C_{8}$ \\
\hline 2,69 & $-0,91$ & $-0,29$ & $-3,45$ & 2,05 & $-3,54$ & 0,80 & 2,64 \\
\hline$D_{1}$ & $D_{2}$ & $D_{3}$ & $D_{4}$ & $D_{5}$ & $D_{6}$ & $D_{7}$ & $D_{8}$ \\
\hline 3,99 & 1,51 & 6,59 & $-6,83$ & 2,37 & $-4,69$ & $-0,47$ & $-2,47$ \\
\hline
\end{tabular}

Table 14 Final tool ranking (ELECTRE II)

\begin{tabular}{|c|c|c|c|c|c|c|c|c|}
\hline Tank & 1 & 2 & 3 & 4 & 5 & 6 & 7 & 8 \\
\hline Tool & 1 & 5 & 3 & 8 & 7 & 2 & 6 & 4 \\
\hline
\end{tabular}

\section{Conclusion}

The choice of the optimal tool for external rough processing by turning can be made using several different methods based on multi-criteria analysis. The final choice depends not only on the input data, but also on the characteristics of each individual method.

The final results are similar for both described methods. The biggest difference is in the ranking of Tool \#4. This was ranked poorly by the ELECTRE II method. ELECTRE II is a non-compensatory method, which means that the lack of one criterion cannot be compensated for by the benefits derived from others. Tab. 1 shows that Tool \#4 has the longest processing time, and this criterion carries the largest weight.

The difference in results of the two methods may be insufficient to choose importance ratios by comparing alternatives, as in Eq. (6) and (7). This can affect the final ranking result, as the alternatives have similar values.

Using the method of multi-criteria decision-making, it is possible to solve specific practical problems. It is important that the comparison method supports more alternatives, according to different criteria, and that it can be described mathematically and then integrated into software. This avoids subjectivity in decision-making with respect to selection of the best solution, facilitating achievement of the ultimate goal.

\section{References}

[1] Balič, J.; Čuš, F. Intelligent modelling in manufacturing. // Journal of Achievements in Materials and Manufacturing Engineering. 24, 1(2007), pp. 340-349.

[2] Čuš, F.; Balič, J. Hybrid ANFIS-ants system based optimisation of turning parameters. // Journal of Achievements in Materials and Manufacturing Engineering. 36, 1(2009), pp. 79-86.

[3] Balič, J.; Čuš, F.; Vaupotič, B. Intelligent automatic cutting-tool selections for turning operations. // The International Congress for global Science and Technology, Proceedings of the International Conference on Artificial Intelligence and Machine Learning / Dubai, 2011, pp. 1-7.
[4] Senthilkumar, N.; Tamizharasan, T.; Anandakrishnan, V. An ANN approach for predicting the cutting inserts performances of different geometries in hard turning. // Advances in Production Engineering \& Management. 8, 4 (2013), pp. 231-241. https://doi.org/10.14743/apem2013.4.170

[5] Mwinuka, T. E.; Mgwatu, M. I. Tool selection for rough and finish CNC milling operations based on tool-path generation and machining optimisation. // Advances in Production Engineering \& Management. 10, 1(2015), pp. 18-26. https://doi.org/10.14743/apem2015.1.189

[6] Hassine, H.; Barkallah, M.; Bellacicco, A.; Louati, J.; Riviere, A.; Haddar, M. Multi Objective Optimization for Sustainable Manufacturing, Application in Turning. // International Journal of Simulation Modelling. 14, 1(2015), pp. 98-109. https://doi.org/10.2507/IJSIMM14(1)9.292

[7] Hrelja, M.; Klancnik, S.; Balic, J.; Brezocnik, M. Modelling of a Turning Process Using the Gravitational Search Algorithm. // International Journal of Simulation Modelling. 13, 1(2014), pp. 30-41. https://doi.org/10.2507/IJSIMM13(1)3.248

[8] Chen, S. J.; Hinduja, S.; Barrow, G. Automatic tool selection for rough turning operations. // International Journal of Machine Tools and Manufacture. 29, 4(1989), pp. 535-553. https://doi.org/10.1016/0890-6955(89)90070-9

[9] Cukor, G.; Jurković, Z.; Sekulić, M. Rotatable central composite design of experiments versus Taguchi method in the optimization of turning. // Metalurgija. 50, 1(2011), pp. $17-20$

[10] Balič, J.; Kovačič, M.; Vaupotič, B. Intelligent programming of $\mathrm{CNC}$ turning operationsusing genetic algorithm. // Journal of Intelligent Manufacturing. 17, 3(2006), pp. 331-340. https://doi.org/10.1007/s10845-005-0001-1

[11] Ehrgott, M. Multicriteria Optimization. Springer, BerinHeideberg, 2005.

[12] Saaty, L. T. Decision making with the analytic hierarchy process. // Int. J. Services Sciences. 1, 1(2008), pp. 83-98. https://doi.org/10.1504/IJSSCI.2008.017590

[13] Teknomo, K. Analytic hierarchy process (AHP) tutorial. http://www.thecourse.us/5/Library/AHP/AHP_Tutorial.pdf. (16.06.2016).

[14] Triantaphylloy, E.; Mann, H. S. Using the analitic hierarchy process for decision making in engineering applications: some challenges. // Int. J. of Industrial Engineering: Applications and Practice. 2, 1(1995), pp. 35-44.

[15] Roy, B. The outranking approach and the foundations of electre methods. // Theory and Decision. 31, 1(1991), pp. 49-73. https://doi.org/10.1007/BF00134132

[16] Elsharida, M. Wael. Application of ELECTRE II method on assessing of construction companies in engineering projects. Atilim University, (2015).

[17] Huang, W. C.; Chen, C. H. Using the electre II method to apply and analyze the differentiation theory. // Proceedings of the Eastern Asia Society for Transportation Studies. 5 (2005), pp. 2237-2249.

\section{Authors' addresses}

\section{Zlatko Botak, PhD}

University North

Department of Mechanical Engineering 104. brigade 3, 42000 Varaždin, Croatia E-mail: zlatko.botak@unin.hr

\section{Jože Balič, PhD}

University of Maribor

Faculty of Mechanical Engineering

Smetanova ulica 17, 2000 Maribor, Slovenia

E-mail: joze.balic@um.si 
Zoran Jurkovic, PhD

University of Rijeka

Faculty of Engineering

Vukovarska 58, 51000 Rijeka, Croatia

E-mail: zoran.jurkovic@riteh.hr 